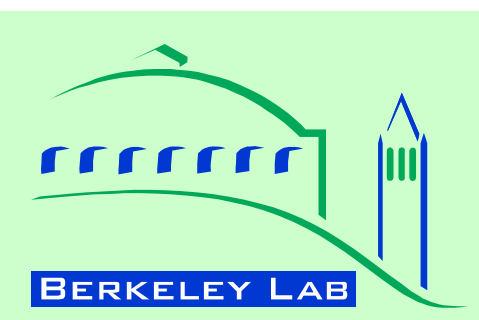

\section{(O) CleanFinergy States Alliance}

\section{CONTENTS}

Introduction 1

Recap of Previous

Findings 2

Implications of the

Revised Residential

Credit 3

Conclusions 11

\section{November 2008}

Download other clean energy fund case studies from:

http://eetd.lbl.gov/ea/EMS/cases/ or

www.cleanenergystates.org

Berkeley Lab and the Clean Energy States Alliance

CASE STUDIES OF STATE SUPPORT FOR RENEWABLE ENERGY

\title{
Shaking Up the Residential PV Market: Implications of Recent Changes to the ITC
}

\author{
Mark Bolinger, Galen Barbose, and Ryan Wiser (Berkeley Lab)
}

\section{Introduction}

On August 8, 2005, the Energy Policy Act of 2005 (EPAct 2005) increased the Section 48 investment tax credit (ITC) for commercial photovoltaic (PV) systems from $10 \%$ to $30 \%$ of the project's "tax credit basis" (i.e., the dollar amount to which the ITC applies), and also created in Section 25D of the Internal Revenue Code a new 30\% ITC (capped at \$2,000) for residential solar systems. Both changes went into effect on January 1, 2006, for an initial period of two years, and in late 2006 both credits were extended "as is" for an additional year (through 2008).

In early 2006, Berkeley Lab published an LBNL/CESA case study that examined the financial impact of EPAct 2005's solar tax credits on PV system owners, in light of the $\$ 2,000$ cap on the residential credit, as well as the fact that most PV systems in the U.S. also receive cash incentives from state-, local-, or utility-administered PV programs, and that these cash incentives may reduce the value of federal tax credits in certain situations. That case study was subsequently revised in February
2007 to reflect new Internal Revenue Service (IRS) guidance.

The findings of that case study, ${ }^{1}$ which are briefly recapped in the next section, remained relevant up until October 2008, when the Energy Improvement and Extension Act of 2008 extended both solar credits for an unprecedented eight years, removed the $\$ 2,000$ cap on the residential credit, and eliminated restrictions on the use of both credits in conjunction with the Alternative Minimum Tax (AMT). ${ }^{2}$ These significant changes, which apply to systems placed in service on or after January 1, 2009, will increase the value of the solar credits for residential system owners in particular, and are likely to spur significant growth in residential, commercial, and utility-scale PV installations in the years ahead.

In light of these substantial changes to the solar ITC, this report takes a

\footnotetext{
1 "Exploring the Economic Value of EPAct 2005's PV Tax Credits" by Mark Bolinger, Ryan Wiser, and Edwin Ing:

http://eetd.lbl.gov/EA/EMP/cases/LBNL 59928.pdf

${ }^{2}$ Less-relevant to this case study, the Act also removed the prohibition on utility use of the Section 48 credit.
} 
fresh look at the value of these revised credits, focusing specifically on the Section 25D residential credit. After first setting the stage by briefly reviewing our previous findings, the document proceeds to cover four specific areas in which the removal of the $\$ 2,000$ cap on the residential ITC will have significant implications for PV program administrators, PV system owners, and the PV industry that go beyond the obvious market growth potential created by these more-lucrative federal incentives. These four areas include:

1) The financial implications of whether or not residential cash rebates are considered to be taxable income;

2) The role of low-interest loan programs and other forms of "subsidized energy financing" under an uncapped ITC;

3) The degree to which taxable and nontaxable rebate levels might be reduced in response to the extra value provided by an uncapped ITC; and

4) The impact of an uncapped ITC on thirdparty financing and ownership models that are just beginning to emerge in the residential sector.

The document concludes by highlighting a common thread that runs throughout: the need for PV program managers to understand whether or not their rebates are considered to be taxable income before they can react in an appropriate manner to the recent changes in federal solar policy and, if financing programs are offered, the need to understand whether the IRS considers these programs to be "subsidized." Finally, we note that this paper is based on current law; future legislative changes to the ITC could, of course, alter the conclusions reached here.

\section{Recap of Previous Findings}

In order to fully grasp the implications of the recent changes to the residential solar ITC, one must first understand the conditions that existed prior to the October 2008 ITC extension and revision. To help foster such an understanding, this section briefly revisits the 2006 LBNL/CESA case study, which found (among other things) that the value of EPAct 2005's solar credits depends on several obvious factors, including:

- System owner: Residential systems face the \$2,000 cap; commercial systems do not.

- System size: Only the smallest residential systems (i.e., less than $1 \mathrm{~kW}$ ) are not bound by the $\$ 2,000$ cap; as system size increases, the relative value of the capped residential credit decreases.

- Tax status of system owner: Tax-exempt system owners, as well as any business or resident paying the alternative minimum tax or without a sufficient tax base, may not be able to directly benefit from the credits (though 3rd-party financing might enable the monetization of some of the credits' value).

In addition, the previous case study found that a not-so-obvious, yet critical, factor in determining the value of the EPAct 2005 credits is whether or not the IRS considers grants or rebates provided by state, local, or utility PV programs to be taxable income. This is still true under the recent changes to the ITC: if the grants provided by these programs are considered to be federally taxable income, then a grant recipient can claim the federal ITC (and depreciation if a commercial system) on the full cost (or tax credit basis) of the system. If, however, the grants are not considered to be taxable income, then the grant recipient must reduce, by the amount of the grant, the basis to which the federal ITC (and depreciation, in the case of commercial systems) applies.

The IRS has provided only limited guidance on whether or under what circumstances PV grants offered by state, local, or utility PV programs should be considered taxable versus non-taxable income. Section 61 of the Internal Revenue Code generally defines gross (taxable) income to mean income derived from any source, except as otherwise provided in statute. Though this suggests that PV grants should generally be considered taxable income (unless statutorily excluded from taxation), the previous case study explored four possible grounds for exclusion from taxation. Specifically, a PV grant would be considered non-taxable if it were found to be one of the following: (1) a government social welfare payment; (2) a manufacturer or dealer rebate of 
the purchase price; (3) a contribution to the capital of a corporation under Section 118 of the Internal Revenue Code; or (4) a utility energy conservation subsidy under Section 136 of the Internal Revenue Code, which applies to residential systems only.

Though it is difficult to generalize, given the highly factual nature of the law surrounding this issue, it appears that state, local, or utility grants made to commercial PV systems will, in most cases, likely not qualify for any of the four exclusions listed above, and will therefore be considered taxable grants that do not reduce the project's basis to which the federal ITC and depreciation apply.

The taxability of a grant made to a residential PV system, meanwhile, will depend on whether or not that grant is considered to be a "utility energy conservation subsidy," which in turn depends on whether the grant program is structured or administered (either directly or indirectly) as a "utility program" under Section 136. Despite several IRS private letter rulings of potential relevance, some uncertainty remains as to what exactly constitutes a "utility program.",

Moreover, the 2006 case study found that because of the $\$ 2,000$ cap on the residential ITC (which will be binding for all but the smallest systems) and the absence of depreciation benefits, residential system owners were generally better off financially with a non-

\footnotetext{
${ }^{3}$ It is clear that eligible subsidy payments provided under a utility-administered program will qualify for the Section 136 exclusion. There is somewhat less clarity on programs administered by governmental entities. Although earlier IRS rulings suggested that a government-administered program would never be considered a utility program (regardless of the funding source), a 2007 private letter ruling concerning the Energy Trust of Oregon (the nonprofit administrator of Oregon's ratepayer-funded PV program) suggests that the IRS will, at least in some cases, consider a utility-ratepayer-funded program that is not administered by a utility to nevertheless be a "utility program" that qualifies for the Section 136 exclusion. Hence, it follows that if a governmental administrator can make a strong case that it is administering a utility program (i.e., that it is passing through utility or ratepayer funding), it is possible that the IRS might find the program eligible for the Section 136 exclusion.
}

taxable, rather than taxable, grant. ${ }^{4}$ That is, in most cases the tax savings from receiving a nontaxable cash rebate (compared to a taxable one) came without negative consequence, because the $\$ 2,000$ ITC cap remained binding even after the basis was reduced accordingly. The opposite was (and still is) true for commercial systems, which are better off paying income tax on the grant, and then applying the uncapped 30\% ITC and accelerated depreciation to the full project cost.

Finally, this preference for non-taxable grants among residential PV owners raised potential implications for PV program administration. Specifically, with the $\$ 2,000$ cap in place, it would be advantageous for most residential PV system owners to have PV incentive programs be structured in a way that would qualify as a "utility program" under Section 136, thereby enabling those programs to provide non-taxable grants to residential system owners.

\section{Implications of the Revised Residential Credit}

With the October 2008 changes to the residential ITC, some of the previous case study's findings with respect to the Section 136 exclusion no longer hold. Moreover, the changes raise several new potential implications for low-interest loan programs, state and local PV program incentive levels, and even third-party ownership models in the residential sector. This section discusses each of these implications in turn.

\section{The Financial Implications of Section 136 Are Now Less Significant for PV System Owners and PV Program Administrators}

Whether or not a residential PV system owner is better off (on net) with a taxable or non-taxable state, local, or utility PV grant depends solely on how that system owner's marginal income tax

\footnotetext{
${ }^{4}$ It is worth noting that the taxpayer is not at liberty to choose whether or not to pay tax on a PV rebate. Instead, a rebate that qualifies for the Section 136 exclusion must be treated as non-taxable, while one that does not qualify must be treated as taxable. It is also worth repeating (from the 2006 case study) that tax implications cannot be avoided or optimized by assigning rebates to installers or third parties; the burden of taxation rests with the intended recipient.
} 
rate compares to the effective (i.e., capped) ITC percentage. If the system owner's tax rate is below the effective ITC percentage, then it is more advantageous to pay tax on the grant and not reduce the ITC basis. Conversely, if the system owner's income tax rate is higher than the effective ITC percentage, then it is more advantageous to not pay tax on the grant and to reduce the ITC basis accordingly.

Whenever the $\$ 2,000$ ITC cap is binding - which it has been for all residential systems larger than roughly $1 \mathrm{~kW}$ - the effective ITC percentage falls below the stated $30 \%$. For a $2 \mathrm{~kW}$ system installed at a cost of $\$ 9.5 / \mathrm{W}$ and receiving a $\$ 3 / \mathrm{W}$ rebate, for example, the effective ITC percentage (under the $\$ 2,000$ cap) is roughly either $10.5 \%$ or $15.5 \%$, depending on whether or not the rebate is taxable. For larger systems, the effective ITC percentage is even lower - e.g., just $6 \%$ or $9 \%$ for a $4 \mathrm{~kW}$ system under the same parameters (but installed for $\$ 8.5 / \mathrm{W}$ ). Since most individual income tax rates are likely to be higher than these effective ITC rates (e.g., in 2007, individual income tax brackets ranged from $10 \%$ to $35 \%$ ), it has - as noted earlier generally been more advantageous for a residential PV owner to receive a non-taxable rebate with the $\$ 2,000$ cap in place (as also mentioned above, the opposite holds true for owners of commercial PV systems, because the $30 \%$ commercial ITC has not been capped and because a non-taxable grant will reduce not only a commercial system's tax credit basis, but also its depreciable basis).

With the removal of the $\$ 2,000$ cap, however, the effective ITC percentage will now always equal $30 \%$. Since $30 \%$ is likely to be higher than most residential system owners' tax brackets (e.g., in 2007, the marginal income tax rate for married couples filing jointly only surpassed 30\% stepping up from $28 \%$ to $33 \%$ - once taxable income exceeded $\$ 196,000$ ), most residential PV system owners are likely to be somewhat better off receiving a taxable grant going forward.

The magnitude of the net difference between a taxable and non-taxable rebate will vary depending on a number of factors. In general, the difference will increase given a higher rebate, a larger PV system, and/or a greater disparity between the effective ITC percentage and the owner's marginal income tax rate. Because the $\$ 2,000$ cap generally exacerbates this disparity by severely curtailing the effective ITC percentage, the magnitude of the difference is generally larger under the capped ITC than it will be going forward under the uncapped ITC.

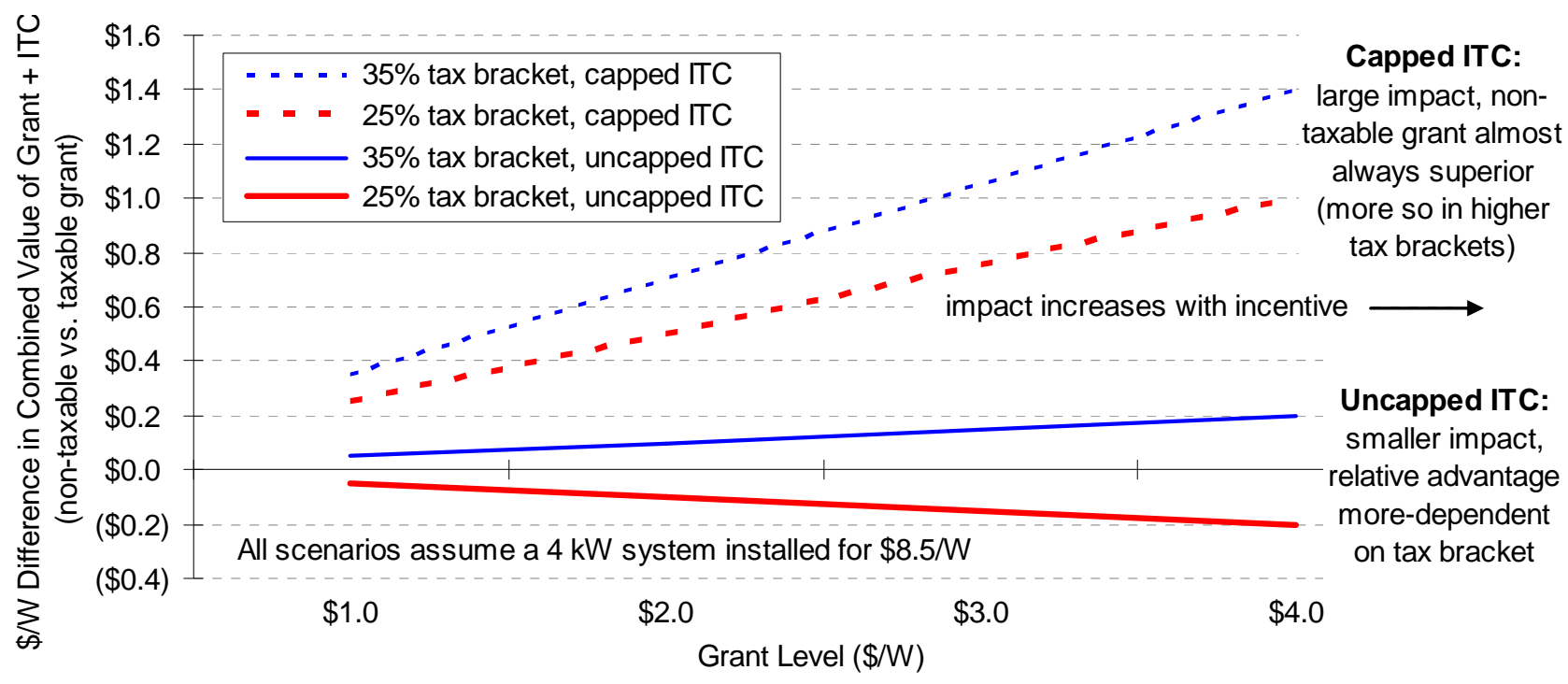

Figure 1. Impact of Tax Treatment of Grants on Residential PV Economics 
Figure 1 illustrates how the magnitude of the difference between a non-taxable and taxable grant (in combination with the ITC) varies across some of these parameters. The two dashed lines, which correspond to an ITC capped at $\$ 2,000$, show that (A) a non-taxable rebate is superior to a taxable rebate when the ITC is capped; (B) the impact is greater for system owners in a higher tax bracket; and (C) the impact increases along with the size of the incentive.

Meanwhile, the two solid lines, which correspond to system owners in the $25 \%$ and $35 \%$ tax brackets receiving an uncapped ITC, are mirror images of one another, reflecting the fact that the two tax brackets equally straddle the effective ITC percentage of 30\%. For reasons explained above, the non-taxable incentive is superior under the $35 \%$ tax bracket, while the taxable incentive is superior under the $25 \%$ tax bracket (at a hypothetical $30 \%$ tax bracket, the taxpayer would be indifferent between a non-taxable or taxable grant). Finally, comparing the two solid lines to the two dashed lines illustrates that the difference between a non-taxable and taxable incentive is significantly larger under a capped ITC.

In summary, although in the past (under the $\$ 2,000$ cap) it has been advantageous for PV program rebates to qualify for the Section 136 exclusion from taxation, that advantage generally no longer holds under an uncapped ITC. In fact, for many PV system owners (especially those in lower tax brackets; those in the two highest tax brackets will still find a non-taxable incentive to be most advantageous), a taxable incentive will be modestly more advantageous beginning on January 1, 2009. At the same time, however, the net financial difference between a taxable and non-taxable rebate going forward will be much smaller than it was under the capped ITC. As such, PV incentive program will likely have little motivation to try to persuade the IRS that they either fall within the Section 136 exclusion, or not, on a going forward basis. ${ }^{5}$

\footnotetext{
${ }^{5}$ One potential implication of this shift, however, involves the likely difference between capacity-based and performance-based incentives (CBIs and PBIs) with respect to Section 136. Specifically, Section 136(a) states that "Gross income shall not include the value of any subsidy
}

\section{Subsidized Loan Programs May No Longer Make Sense for Many Residential PV Owners}

A number of state and local government agencies offer low-interest loan programs to help finance the installation of energy efficiency measures and/or renewable energy systems. Due to its high up-front cost and widespread appeal, residential PV is frequently a target of such programs. Although low-interest loan programs can ease the burden of purchasing a PV system, it should be recognized that if such programs are considered by the IRS to be "subsidized energy financing," then the dollar value of the ITC must be reduced by the dollar amount financed in this manner.

Specifically, Section $25 \mathrm{D}(\mathrm{e})(9)$ of the Internal Revenue Code states, with respect to the tax basis of the project, that "For purposes of determining the amount of expenditures made by any individual with respect to any dwelling unit, there shall not be taken into account expenditures which are made from subsidized energy financing (as defined in section 48 (a)(4)(C))." In other words, the tax basis of the project to which the credit applies shall be reduced by the amount of any subsidized energy financing used to finance the system.

\footnotetext{
provided (directly or indirectly) by a public utility to a customer for the purchase or installation of any energy conservation measure" [italics added]. Since PBIs do not directly assist with the purchase or installation of the PV system, but instead augment the revenue generated by the system, one might argue that PBIs do not fall under Section 136, and therefore are considered taxable income. A second reason that PBIs do not fit well under Section 136 is that if PBIs were found to be non-taxable under Section 136, it is unclear how system owners would go about reducing the tax basis of the system for the purpose of applying the ITC, given that the PBI is earned over time, with the exact dollar amount known only in retrospect.
}

Assuming, for these reasons, that residential PBIs will always be taxable, a program administrator whose rebate program otherwise falls under Section 136 could potentially increase the net impact of its incentives for PV system owners in lower tax brackets by switching from grants or rebates to PBIs. For the same reason, existing programs that allow residential participants to choose either a CBI or a PBI (e.g., the California Solar Initiative) may see greater interest in the PBI option starting in 2009, at least among those participants in lower tax brackets. Of course, these possible tax advantages to PBIs may be offset by other, unrelated disadvantages to PBIs in the residential sector. 
Section 48(a)(4)(C), meanwhile, defines the term "subsidized energy financing" to mean "...financing provided under a Federal, State, or local program a principal purpose of which is to provide subsidized financing for projects designed to conserve or produce energy." The instructions to IRS Form 6497 ("Information Return of Nontaxable Energy Grants or Subsidized Energy Financing") expand upon the Section 48 definition, noting that "Financing is subsidized if the terms of the financing provided to the recipient in connection with the program or used to raise funds for the program are more favorable than terms generally available commercially." Moreover, "The source of the funds for a program is not a factor in determining whether the financing is subsidized."

A number of existing loan programs clearly fall into the category of subsidized energy financing. In New York, for example, the Energy Smart Loan Program adds value by reducing the interest rate offered by commercial lenders by up to $4 \%$ (e.g., a 7\% bank loan would cost the borrower as little as 3\%). The resulting interest rate is clearly "more favorable than terms generally available commercially," and the IRS would therefore presumably categorize this program as offering subsidized energy financing.

Other cases are less clear-cut. For example, a number of municipalities throughout the U.S. are currently implementing innovative financing programs that combine attractive loan terms with repayment through higher property tax assessments. Most strongly identified with the City of Berkeley, California, which first proposed the idea, this type of program may or may not constitute subsidized energy financing. ${ }^{6}$ More generally, the IRS has not yet offered definitive guidance on what constitutes subsidized energy financing in these and other cases.

With the residential ITC capped at just $\$ 2,000$, the loss of the ITC due to the use of subsidized energy financing has - up to this point - not

\footnotetext{
${ }^{6}$ For more information on this issue as it relates to Berkeley's program, see "Property Tax Assessments as a Finance Vehicle for Residential PV Installations: Opportunities and Potential Limitations", available at: http://eetd.lbl.gov/EA/EMP/cases/property-tax-finance.pdf
}

necessarily been a losing proposition. Depending on the specifics of the program, attractive financing terms may actually outweigh the loss of the ITC. This is particularly true for larger residential PV systems, where the capped ITC represents a smaller proportion of the overall costs that need to be financed. And, of course, such financing programs may offer other benefits to consumers as well.

Now that the cap has been lifted, however, much more economic value is at stake. Picking up on our previous example, a $4 \mathrm{~kW}$ system installed at $\$ 8.5 / \mathrm{W}$ and receiving a $\$ 3 / \mathrm{W}$ rebate will now be eligible for an ITC of either $\$ 10,200$ or $\$ 6,600$, depending on whether or not the rebate is taxable. The loss of this amount of tax credit value (or some fraction thereof, if only a portion or the system is financed through such a program) will obviously impinge upon system economics much more so than the loss of just $\$ 2,000$, and will likely make even the mostaggressive low-interest loan programs uneconomical. Such programs, however, may continue to fill an important need for those residents who are unable to make efficient use of the uncapped ITC (e.g., by having to continuously roll it forward for a number of years before fully absorbing it).

In an uncapped ITC environment, and under current law, the value of PV financing programs could potentially be optimized by providing favorable terms other than reduced interest rates. For example, a market-rate loan program that features a no-hassle application and approval process, no collateral requirements, no closing fees, and extended maturities, might still provide value, but might not be considered subsidized energy financing. Some of the municipal property-tax-based PV programs that are emerging may fit this bill, for example, by offering an innovative and extended loan repayment method (i.e., tied to property taxes) that is nevertheless financed at market rates. Alternatively, if a utility could be persuaded to offer a low-interest PV loan program, this might not be considered subsidized energy financing, if the program was not considered by the IRS to be "a Federal, State, or local program." Informed legal counsel should be consulted to determine 
whether such approaches might work, however, because the IRS has not offered definitive guidance on whether any of the program ideas noted here would or would not be considered subsidized energy financing; IRS rulings will likely be required to reach definitive conclusions.

In the meantime, one thing is clear: it is now more important that ever to understand whether or not a loan program is at risk of being considered "subsidized energy financing," and to take steps to minimize the potential for such a characterization.

\section{State, Local, and Utility PV Programs Can Potentially Reduce Residential Incentive Levels Without Negatively Impacting the Market}

With the exception of the smallest systems, which have not been impacted by the $\$ 2,000$ cap on the residential ITC, most residential PV systems installed starting in 2009 will realize significant additional value from the elimination of the ITC cap. State, local, and utility PV program administrators may, in turn, wish to capture at least some of this incremental value by reducing their incentive levels.

Assuming that current residential rebates are set at a level that provides the desired amount of support to the residential sector (i.e., assuming no adjustments to rebate levels need to be made apart from those related to the removal of the ITC cap), Figures 2 and 3 show the maximum amount by which these rebate levels could - in theory - be reduced (starting in 2009 , once the ITC cap is gone) without leaving system owners any worse off on an after-tax basis than they are now under current rebate levels and the $\$ 2,000$ ITC cap. Figure 2 shows this amount for nontaxable rebates, while Figure 3 provides the same information for taxable rebates.

For non-taxable rebates (Figure 2), the magnitude of the potential rebate reduction depends only on the size and cost of the system, ${ }^{7}$ as well as the starting (or "current") rebate level; the system owner's income tax bracket does not factor in to

\footnotetext{
${ }^{7}$ Both Figures 2 and 3 assume that per-unit installed costs decline along a concave curve from $\$ 10.50 / \mathrm{W}$ at $0.5 \mathrm{~kW}$ to $\$ 7.75 / \mathrm{W}$ at $10 \mathrm{~kW}$.
}

the calculation, because the rebates are nontaxable. As shown, small systems $(0.5 \mathrm{~kW}-2$ $\mathrm{kW}$ ) cannot withstand as much of a rebate reduction as can larger systems, because smaller systems will benefit less from the removal of the $\$ 2,000$ cap (i.e., they were not as impacted by the cap in the first place). Above roughly $3 \mathrm{~kW}$, however, the curves more or less level out, revealing that a rebate currently set at $\$ 1 / \mathrm{W}$ could be reduced by as much as $\$ 2.5 / \mathrm{W}$ (in theory, going negative ${ }^{8}$ ) without leaving the system owner any worse off on an after-tax basis. Meanwhile, starting with a non-taxable rebate of $\$ 4 / \mathrm{W}$, the size of the potential reduction is smaller, at roughly $\$ 1.25 / \mathrm{W}$ (starting rebate levels of $\$ 2 / \mathrm{W}$ and $\$ 3 / \mathrm{W}$ fall in between these two extremes). This rank-ordering makes intuitive sense: a small non-taxable rebate reduces the ITC's basis by less than does a large one, which means that the removal of the $\$ 2,000$ ITC cap provides greater benefit to a system receiving a smaller non-taxable rebate. Such a system can, in theory, therefore withstand a larger reduction in the size of the rebate.

For taxable rebates (Figure 3), the size of the potential rebate reduction depends only on the size and cost of the system, as well as the system owner's federal income tax bracket; the starting rebate level does not factor in to the calculation, because taxable rebates do not reduce the ITC's basis. As shown, the curves look similar to those in Figure 2, rising rapidly up to about $3 \mathrm{~kW}$, after which they level out. At that point, taxable rebates could be reduced anywhere from $\$ 2.3 / \mathrm{W}$ to $\$ 3.2 / \mathrm{W}$, depending on the owner's federal tax bracket (all six tax brackets that existed in 2007 are shown in Figure 3). System owners in higher tax brackets can withstand a larger rebate reduction than those in lower brackets, because the formers' tax burden is reduced relatively more as the rebate level drops (i.e., the benefit of paying less income tax on a $\$ 2 / \mathrm{W}$ rebate than on a $\$ 4 / \mathrm{W}$ rebate is greater for those in higher tax brackets; hence they can withstand a larger rebate reduction).

\footnotetext{
${ }^{8}$ Although a negative rebate is obviously not a practical outcome (i.e., rebates would never fall below $\$ 0$ ), we express the results of the analysis in this way to demonstrate the relative magnitudes at stake.
} 


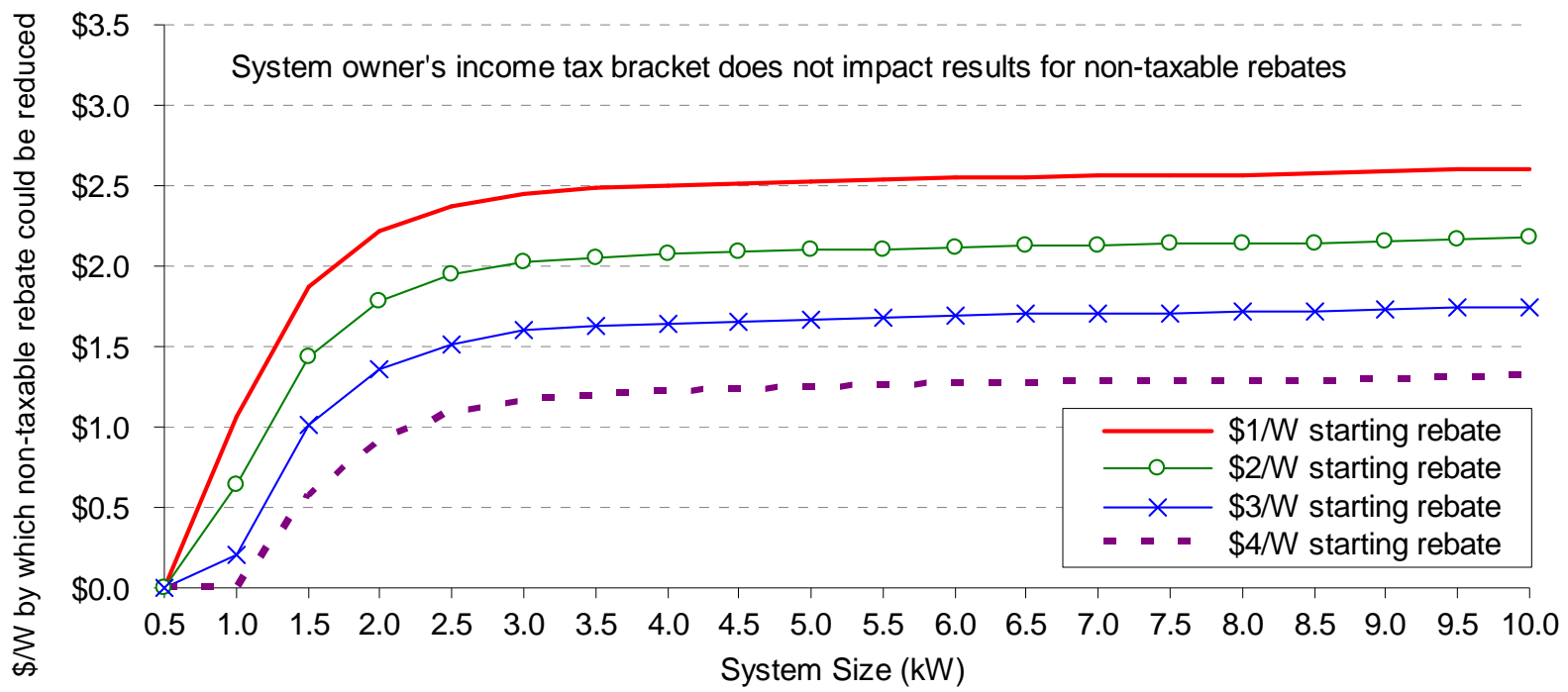

Figure 2. The Maximum Amount By Which A Non-Taxable Rebate Can Be Reduced In Response To The Removal Of The \$2,000 Cap On The Residential ITC

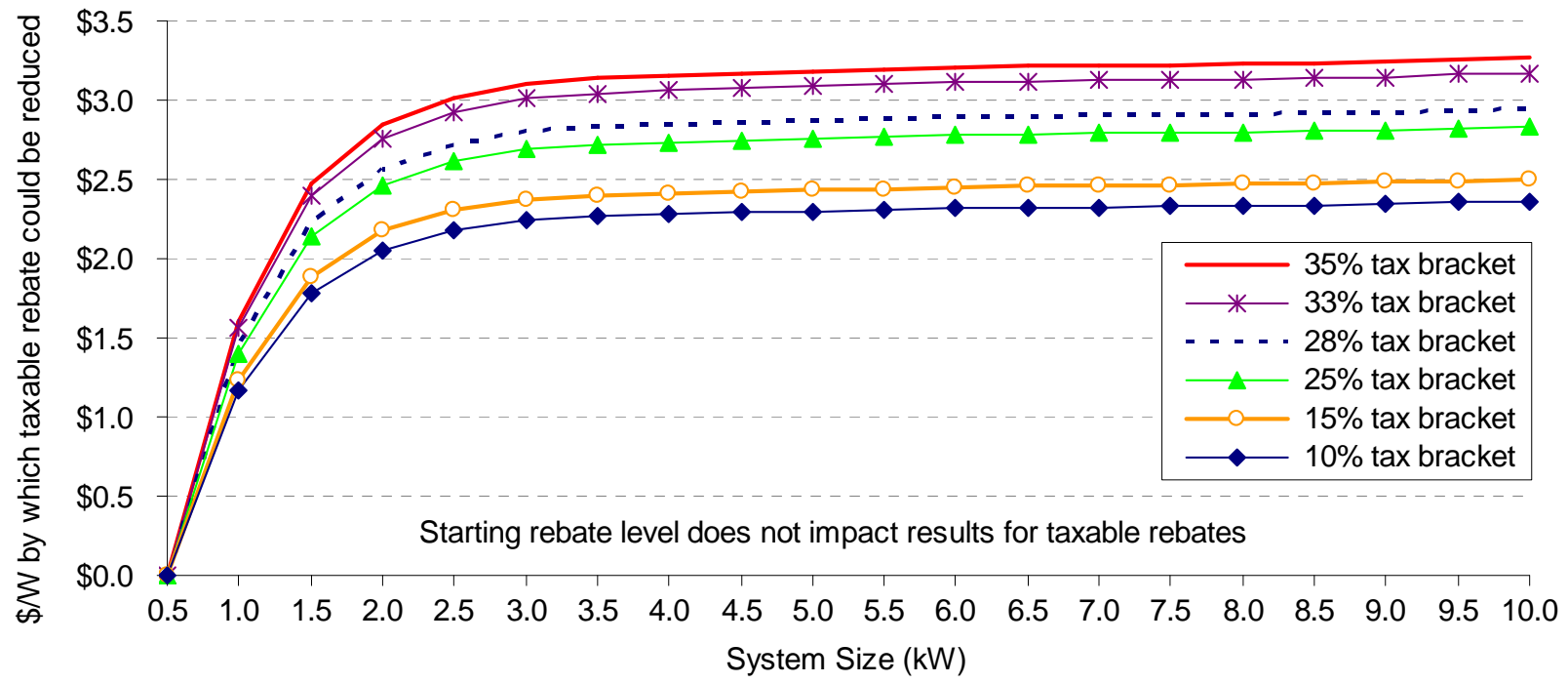

Figure 3. The Maximum Amount By Which A Taxable Rebate Can Be Reduced In Response To The Removal Of The \$2,000 Cap On The Residential ITC

In response to the lifting of the residential ITC cap, several state, local, and utility PV programs have reduced the level of the incentives that they will provide to residential PV systems. A number of other programs are considering doing the same.

The Connecticut Clean Energy Fund, for example, has reduced its residential PV incentive from $\$ 5 / \mathrm{W}$ to $\$ 4 / \mathrm{W}$ (a $\$ 1 / \mathrm{W}$ reduction) for the first $5 \mathrm{~kW}$ installed, and from $\$ 4.30 / \mathrm{W}$ to $\$ 2.50 / \mathrm{W}$ (a $\$ 1.80 / \mathrm{W}$ reduction) for the next 5
$\mathrm{kW}$. The larger reduction for the sixth through tenth $\mathrm{kW}$ reflects the fact that the abolishment of the cap benefits larger systems more than smaller systems, as shown in Figures 2 and 3.

In Colorado, the investor-owned utility Xcel Energy has reduced (only for systems less than $10 \mathrm{~kW}$ ) the up-front, lump-sum amount that it will pay for a PV system's solar renewable energy certificates (SRECs) from $\$ 2.50 / \mathrm{W}$ to $\$ 1.50 / \mathrm{W}$. The additional $\$ 2 / \mathrm{W}$ rebate provided 
by Xcel remains unchanged, for a total up-front incentive of $\$ 3.50 / \mathrm{W}$. $^{9}$

The California Energy Commission has decided to leave incentives for the New Solar Homes Partnership unchanged in an effort to boost the appeal of PV and also mitigate some of the negative impact of the distressed housing market. Meanwhile, the California Public Utilities Commission, which administers the other California Solar Initiative programs, is accepting public comment on whether to change its incentives in response to the ITC changes; initial comments are due November 20, with reply comments due on December 4.

The New Jersey Board of Public Utilities is also accepting public comment on what changes, if any, should be made to New Jersey's incentive levels. Comments are due on November 21, and staff expect to make a recommendation to the Board on December 8.

While the idea of shifting part of the cost of supporting residential $\mathrm{PV}$ to the federal government must look quite appealing to many PV program managers (e.g., allowing them to stretch fixed budgets to support additional installations), there are, nevertheless, several factors that program managers may wish to consider when deciding by how much to reduce residential incentive levels, and that may suggest that incentives should not be cut by as much as Figures 2 and 3 show may be possible. These considerations include the following:

- PV system owners may have to wait up to a year or more (depending on how early in the year the system is installed) before they file their tax returns and realize the benefit of the ITC. During this waiting period, the accrued dollar benefit of the ITC must effectively be financed by some other means, which renders the ITC less-useful than an equivalent up-front cash incentive.

\footnotetext{
${ }^{9}$ Interestingly, if Xcel's rebate falls under the Section 136 exclusion from taxation while its up-front SREC payment does not (since the latter is a payment in exchange for SRECs, rather than a "subsidy"), then the negative impact of a $\$ 1 / \mathrm{W}$ reduction on most prospective residential PV system owners would have been less severe if the cut had been made to the rebate rather than to the up-front REC purchase.
}

- With the $\$ 2,000$ cap removed, the uncapped ITC may be too large for some taxpayers to absorb in the first year, or perhaps ever (in the most extreme cases). For example, a $4 \mathrm{~kW}$ system costing $\$ 8.5 / \mathrm{W}$ will, starting in 2009 , be eligible for an ITC of $\$ 10,200$ (assuming no subsidized energy financing or non-taxable incentives). The taxpayer owning this system must have an income tax liability of at least $\$ 10,200$ in the year the system is installed in order to make efficient use of the credit. Although any unused portion of the credit can be rolled forward for 20 years, doing so reduces the value of the credit in current dollars.

- In recent years, the PV market in the U.S. has been increasingly dominated by the commercial sector, which has not only been more-heavily subsidized by federal tax policy, but also somewhat surprisingly by some PV programs as well. ${ }^{10}$ Maintaining the status quo on residential incentives, or reducing them by less than is possible, may help to restore more of a balance between the residential and commercial markets.

- Somewhat related, Figures 2 and 3 presume that current or starting rebate levels are set at the "correct" or "optimal" level to provide the desired amount of support to the residential sector. If this is not the case - e.g., if current residential incentive levels are too low to adequately stimulate desired market demand - then the results shown in Figures 2 and 3 may be too aggressive.

- Finally, leaving residential incentives unchanged should accelerate the adoption of residential PV at no extra per-system cost to the program. This motivation, however, must be weighed against the foregone benefit of any additional installations that could be supported by reducing incentive levels and thereby stretching fixed program budgets.

\footnotetext{
${ }^{10}$ Ryan Wiser, Galen Barbose, Carla Peterman. 2008. “An Empirical Investigation of PV Cost Trends, and Implications for Incentive Program Design.” Presentation at Solar Power International, San Diego, California, October 15, 2008.
} 


\section{Third-Party Ownership Structures Now Hold Somewhat Less Economic Appeal In The Residential Sector}

For several years now, the non-residential sector has benefited from third-party PV financing structures, including leasing and power purchase agreements (PPAs), that enable site hosts to "go solar" without the associated up-front costs and, in some cases, risks of ownership. ${ }^{11}$ By engaging "tax equity" investors with an appetite for tax credits, these structures also enable the efficient use of the substantial tax benefits (consisting of the ITC and accelerated depreciation) provided to a commercial PV project. These tax benefits, which on a present value basis equal roughly $56 \%$ of the installed cost of a commercial PV system, ${ }^{12}$ are often too large for a commercial site host to efficiently absorb on its own, and are completely unavailable to tax-exempt site hosts. Through third-party ownership, the value of these tax benefits can be monetized and passed through to the site host in the form of lower lease or PPA payments.

One would think that, other potential benefits aside, the ability to monetize and pass along the higher tax benefits available to commercial owners would make the residential sector a particularly attractive market for third-party ownership. Yet, due to a combination of heightened credit concerns, larger proportional transaction costs, and a simple need to first gain comfort with the structures in a commercial setting, third-party ownership has been somewhat

\footnotetext{
${ }^{11}$ For more information on third-party ownership structures, see LBNL's "Financing Non-Residential Photovoltaic Projects: Options and Implications", soon to be available at http://eetd.lbl.gov/EA/EMP/re-pubs.html

${ }^{12}$ Specifically, $30 \%$ comes from the ITC and another $26 \%$ from 5-year accelerated depreciation. It is worth noting, however, that relative to a 20 -year straight-line depreciation schedule that might otherwise be used if solar did not qualify for the accelerated 5-year schedule, the present value benefit of accelerated depreciation comes to just $12 \%$ (rather than $26 \%$ ) of installed costs. In other words, since all commercial assets are depreciated in one way or another, the $26 \%$ absolute number overstates the incremental incentive provided by an accelerated schedule. Compared to residential systems, however, which cannot be depreciated at all for tax purposes, the $26 \%$ absolute number is the correct point of comparison.
}

slower in coming to the residential sector than to the commercial sector.

Within the past year, however, several PV installers have begun to offer third-party leases and PPAs to the residential sector. In addition, one publicly sponsored residential leasing program - the Connecticut Solar Lease program - has been launched.

With the removal of the $\$ 2,000$ ITC cap, at least one of the tax advantages of these third-party ownership programs for the residential sector has been diminished. With the $\$ 2,000$ cap in place, the residential ITC's value equals roughly $10 \%$ of the installed cost of a $2 \mathrm{~kW}$ system, and even less for larger systems. This compares quite poorly with the $56 \%$ figure (which includes both the ITC and accelerated depreciation - residential systems cannot be depreciated for tax purposes) presented above for commercial systems, and highlights the significant arbitrage opportunity presented by commercial third-party ownership in the residential sector. With the $\$ 2,000$ residential ITC cap eliminated starting in 2009, however, the comparison going forward will still favor commercial systems (due to accelerated depreciation), but by a smaller margin: $56 \%$ for commercial systems versus $30 \%$ for residential.

The removal of the $\$ 2,000$ ITC cap does not, however, sound the death knell of third-party ownership in the residential sector. Indeed, though greatly diminished, a sizable arbitrage opportunity (equal to $26 \%$ of installed costs) still exists. Furthermore, as discussed earlier, with "subsidized" financing programs no longer making much sense for PV, and with state and local PV programs reducing their residential incentive levels in response to the ITC revisions, there are likely to be fewer financing options available to cash-strapped prospective PV owners, potentially creating a greater need for third-party ownership. Finally, third-party ownership provides other potentially attractive benefits besides tax credit monetization (e.g., no performance risk); these benefits may ultimately trump more-traditional financial considerations. 


\section{Conclusions}

Although policy support for emerging technologies generally seeks to reward early adopters, in the case of the Section 25D residential ITC, procrastinators have been the beneficiaries - initially in 2006 when the capped ITC was first implemented, and again in October 2008 when the $\$ 2,000$ cap was eventually lifted. Though welcomed by the industry and prospective PV owners, these changes in federal tax policy have necessitated reactive planning at the state and local levels.

This case study has highlighted a number of ways in which state, local, and utility PV program administrators must remain nimble in responding to the recent changes in federal solar policy:

- Most obviously, program managers may wish to reduce their incentive levels to at least partially compensate for the morevaluable ITC.

- Complementary low-interest loan programs that can be characterized as "subsidized energy financing" may no longer make sense for residential PV, and should potentially be re-tooled (to focus on providing "unsubsidized" support) or redirected at other clean technologies for which subsidized energy financing is not as large of an issue.

- At the same time, third-party financing and ownership models that have recently begun to make inroads into the residential sector may now face a somewhat harder sell. Thus, there may be a continuing need for policies that address financial barriers and support innovative financing models.

- Finally, any previous motivation for PV program administrators to structure their programs as a "utility program" under Section 136 (in order to offer non-taxable incentives) has now been largely removed, or even reversed.

A critical prerequisite to knowing how to react to some of these changes is a solid understanding of whether or not a program's incentives are currently treated as taxable income. For example, an incentive level reduction that seems reasonable given a taxable incentive may be too severe if the incentive is, in fact, non-taxable. Likewise, attempting to optimize incentive value through program structure (i.e., whether the program is defined as a "utility program" under Section 136) requires knowing where a program currently stands from a tax standpoint. Finally, one must also take this taxable/non-taxable distinction into account when running the numbers to evaluate whether or under what circumstances subsidized energy financing programs still make sense on net (of course, one also needs to know whether the program in question does, in fact, constitute "subsidized energy financing").

For these reasons, PV program administrators that do not yet know whether or not their incentives are taxable are encouraged to seek qualified legal counsel, or even IRS guidance, to put this question to rest once and for all. Similarly, programs that offer low-interest loans are encouraged to seek guidance from the IRS on whether or not those loan programs are considered to be "subsidized energy financing."

The eight-year extension of the ITC provides a long-term and relatively stable federal policy environment for PV. By making informed programmatic changes in response to the new federal solar policy landscape, PV program administrators can capitalize on and contribute to this unprecedented stability. 


\section{About this CASE Study SeRIES}

A number of U.S. states have established clean energy funds to support renewable and clean forms of electricity production. This represents a new trend towards aggressive state support for clean energy, but few efforts have been made to report and share the early experiences of these funds.

This paper is part of a series of clean energy fund case studies prepared by Lawrence Berkeley National Laboratory and the Clean Energy States Alliance. The primary purpose of this case study series is to report on the innovative programs and administrative practices of state (and some international) clean energy funds, to highlight additional sources of information, and to identify contacts. Our hope is that these case studies will be useful for clean energy funds and other stakeholders that are interested in learning about the pioneering renewable energy efforts of clean energy funds. To access or download all the case studies, see: http://eetd.lbl.gov/ea/ems/cases/ or http://www.cleanenergystates.org/

\section{About the Clean Energy States Alliance}

The Clean Energy States Alliance (CESA) is a non-profit initiative funded by members and foundations to support the state clean energy funds. CESA collects and disseminates information and analysis, conducts original research, and helps to coordinate activities of the state funds. The main purpose of CESA is to help states increase the quality and quantity of clean energy investments and to expand the clean energy market. The Clean Energy Group manages CESA, while Berkeley Lab provides CESA with analytic support.

\section{Contact the Managers of the CaSe Study Series}

\author{
Ryan Wiser \\ Berkeley Lab \\ 510-486-5474 \\ rhwiser@lbl.gov
}

\author{
Mark Bolinger \\ Berkeley Lab \\ 603-795-4937 \\ mabolinger@lbl.gov
}

\author{
Mark Sinclair \\ Clean Energy States Alliance \\ 802-223-2554 \\ msinclair@cleanegroup.org
}

\section{ACKNOWLEDGEMENTS}

Berkeley Lab's contributions to this case study series are funded by the Clean Energy States Alliance, and by the U.S. Department of Energy (the Office of Energy Efficiency and Renewable Energy, Solar Energy Technologies Program, as well as the Office of Electricity Delivery and Energy Reliability, Permitting, Siting and Analysis) under Contract No. DE-AC02-05CH11231. The authors thank the following individuals for reviewing and providing comments on earlier drafts of this document: Karlynn Cory and Jason Coughlin (NREL), Ed Ing (Law Offices of Edwin T.C. Ing), Tom Kimbis and Larry Mansueti (U.S. DOE), and Mark Sinclair (CESA).

\section{DISCLAIMER}

This document was prepared as an account of work sponsored by the United States Government. While this document is believed to contain correct information, neither the United States Government nor any agency thereof, nor The Regents of the University of California, nor any of their employees, makes any warranty, express or implied, or assumes any legal responsibility for the accuracy, completeness, or usefulness of any information, apparatus, product, or process disclosed, or represents that its use would not infringe privately owned rights. Reference herein to any specific commercial product, process, or service by its trade name, trademark, manufacturer, or otherwise, does not necessarily constitute or imply its endorsement, recommendation, or favoring by the United States Government or any agency thereof, or The Regents of the University of California. The views and opinions of authors expressed herein do not necessarily state or reflect those of the United States Government or any agency thereof, or The Regents of the University of California. 